\title{
RANCANGAN PERATURAN DAERAH KABUPATEN PONOROGO TENTANG LARANGAN PERCERAIAN BAGI TENAGA KERJA INDONESIA PERSPEKTIF HUKUM ISLAM
}

\author{
Siti Tatmainul Qulub, Ahmad Munif \\ Universitas Islam Negeri Sunan Ampel Surabaya, Universitas Islam Negeri Walisongo \\ Semarang | Jl. A. Yani I I 7 Surabaya, JI. Walisongo 3-5 Semarang \\ nungky_diamond@yahoo.com, munif060386@gmail.com
}

\begin{abstract}
Since 2015 the regency of Ponorogo planned to issue a bylaw which prevent indonesian migrant workers who work overseas to divorce. The plan included the prohibition against lawyers to represent migrant workers in divorce cases. The consideration of the bill is the prevalent cases of divorce among migrant workers in the regency. As a regency with a large number of migrant workers, the regulation is expected to mitigate social problems caused by high divorce rate. This is in accordance with the principle of maslahah (welfare) since it will guarantee the protection of family which is one of five basic protection in the concept of maqasid al-shari'ah (the purpose of islamic law). Therefore, the plan should be supported and implemented. In addition, intensive family councelling should be initiated for workers prior and after working overseas.
\end{abstract}

Keywords: Bylaw, divorce prohibition, migrant workers

Abstrak: Pemerintah Daerah Kabupaten Ponorogo berinisiatif mengeluarkan Peraturan Daerah tentang Larangan Perceraian bagi Tenaga Kerja Indonesia (TKI) yang berada di luar negeri. Perda tersebut hingga saat ini masih belum disahkan dan ditetapkan, padahal Perda ini telah dibahas dan digodok dari sejak tahun 20 I5. Inisiasi dari Perda ini berangkat permasalahan tingginya kasus perceraian TKI di Kabupaten Ponorogo, di mana Ponorogo merupakan salah satu pemasok TKI yang besar di Jawa Timur. Dampak negatif dari profesi Tenaga Kerja Indonesia diantaranya adalah perceraian. Dengan mempertimbangkan urgensi dan kemaslahatan yang ditaksirkan dapat meminimalisasi terjadinya perceraian di Ponorogo, sebaiknya Perda tersebut segera disahkan dan ditetapkan agar dampaknya dapat segera dirasakan oleh masyarakat. Hal ini sejalan dengan tujuan hukum Islam yang terumuskan 
dalam al-kulliyyât al-khamsah, yaitu: hifzh al-dîn, hifzh al-nafs, hifzh al'aql, hifzh al-nasab dan hifzh al-mâl. Di samping Perda, perlu peraturan lain tentang tidak diperbolehkannya mewakilkan proses perceraian kepada pengacara untuk meminimalisasi perceraian di Ponorogo. Selain itu, upaya penyuluhan juga perlu dilakukan oleh Pemerintah Daerah bagi TKI, baik pra maupun pasca pemberangkatan TKI ke luar negeri.

Kata Kunci: Rancangan Peraturan Daerah, larangan perceraian, Tenaga Kerja Indonesia, hukum Islam.

\section{Pendahuluan}

Pemerintah Kabupaten Ponorogo membuat Rancangan Peraturan Daerah (Raperda) yang tampaknya cukup unik dibandingkan dengan peraturan daerah yang ada, yaitu larangan cerai bagi tenaga kerja wanita atau tenaga kerja pria (TKI) di luar negeri. Larangan tersebut berlaku bagi warga Kabupaten Ponorogo yang sedang bekerja menjadi tenaga kerja wanita atau tenaga kerja pria untuk mengajukan permohonan perceraian, baik gugat cerai ataupun cerai talak.

Menurut Sumani, Kepala Dinas Sosial Tenaga Kerja dan Transmigrasi Ponorogo, Rancangan Peraturan Daerah tersebut sudah dibahas hingga tingkat DPRD Ponorogo dan sudah dikonsultasikan dengan Pemprov Jawa Timur, hanya menunggu keputusan untuk disetujui atau ditolak sebagai sebuah Perda yang mengikat warga Kabupaten Ponorogo. ${ }^{1}$

Banyaknya kasus perceraian yang terjadi pada keluarga TKW/TKI menjadi latar belakang yang menginisiasi Raperda tersebut. Dengan disahkannya Perda larangan perceraian bagi TKW/TKI yang sedang bekerja di luar negeri, diharapkan mampu mencegah bahkan mengurangi angka kasus perceraian yang tinggi di Kabupaten Ponorogo. Mengingat banyaknya kasus perceraian yang terjadi di Kabupaten tersebut didominasi oleh cerai gugat, dan

Muhlis Al Alawi, "Pemkab Ponorogo Buat Perda Larangan TKI Cerai", dalam http://regional.kompas.com/read/20 I 6/I I/08// 644343 I/pemkab.ponorogo.buat.perda.larangan. tki.cerai, diakses tanggal 28 Januari 2017. 
$40 \%$ di antaranya adalah cerai gugat yang dilakukan oleh tenaga kerja wanita yang sedang bekerja di luar negeri. ${ }^{2}$

Sebagaimana diketahui bahwa Indonesia merupakan salah satu negara pemasok tenaga kerja yang cukup besar. Sampai dengan tahun 2014, berdasarkan data yang diperoleh dari Badan Nasional Penempatan dan Perlindungan Tenaga Kerja Indonesia (BNP2TKI), diketahui bahwa jumlah tenaga kerja wanita di luar negeri dari Jawa Timur sebanyak 49.582 orang. Lima Kabupaten/Kota yang mempunyai tenaga kerja wanita luar negeri terbanyak antara lain: Kabupaten Malang (6.433 orang), Ponorogo (6.343 orang), Kabupaten Blitar (6.029 orang) Banyuwangi (5.384 orang) dan Kabupaten Madiun (3.714 orang). Sementara itu tren penempatan tenaga kerja wanita di luar negeri selama tiga tahun yaitu tahun 2012, 2013 dan 2014 menunjukkan pola yang konsisten dengan Kabupaten/Kota yang mempunyai TKI wanita terbanyak di Jawa Timur, yaitu Malang, Ponorogo dan Blitar.

Tren tersebut ternyata berbanding lurus dengan kasus perceraian yang semakin meningkat dari tahun ke tahun di Kabupaten/Kota tempat TKI tersebut berasal. Kasus perceraian dapat dikatakan sebagai dampak negatif dari adanya profesi Tenaga Kerja Indonesia yang bekerja di luar negeri, di samping dampak positif yang dihasilkan yaitu meningkatnya pendapatan dan devisa negara. ${ }^{3}$ Dari 38 Pengadilan Agama di Jawa Timur, Pengadilan Agama Malang menempati urutan pertama dalam menangani kasus perceraian, yakni 7.479 kasus, disusul Pengadilan Agama Kabupaten Banyuwangi 6.794 kasus, Pengadilan Agama kota Surabaya dengan 6.529 kasus, Pengadilan Agama Kabupaten Jember dengan 4.609 kasus, sedangkan Pengadilan Agama Kabupaten Blitar menempati urutan kelima dengan 34.609 kasus. ${ }^{4}$ Selanjutnya adalah Kabupaten Ponorogo dengan kasus perceraian

\footnotetext{
${ }^{2}$ Ibid.

3 Sulthon Miladiyanto, "Pengaruh Profesi Tenaga Kerja Indonesia (TKI) Terhadap Tingginya Perceraian di Kabupaten Malang", Jurnal Moral Kemasyarakatan, Vol. I, No. I, (Juni 20 I6), 5 I-66. ${ }^{4}$ http://www.surabayapost.co.id diakses pada tanggal 20 Februari 2017.
} 
yang terjadi dari Januari-Juni 2016 sebanyak 1.272 berupa cerai talak, 2.346 kasus adalah cerai gugat, sedangkan yang sudah diputus adalah 1.103 kasus. $^{5}$

Tingginya kasus perceraian di Kabupaten Ponorogo salah satunya diakibatkan oleh adanya aturan yang membolehkan TKW yang masih berada di luar negeri dapat menggugat cerai pasangannya melalui jasa pengacara. Dalam aturan tersebut, pihak pengacara mendapat surat kuasa dari TKW yang diberikan melalui kedutaan besar Indonesia di luar negeri. Dengan surat kuasa tersebut, persidangan dapat berjalan dengan mewakilkan pihak yang berperkara (TKW) kepada pengacara. ${ }^{6}$ Kemudahan prosedur perceraian tersebut banyak dimanfaatkan oleh TKW, sehingga membuat tingginya kasus perceraian dengan dominasi gugat cerai dari tenaga kerja wanita yang masih berada di luar negeri.

Peraturan Daerah tentang Larangan Cerai bagi Tenaga Kerja Indonesia (TKI) sudah lama digodog di DPRD Ponorogo. Pada tanggal 3 April 2015 sudah dilakukan gelar uji publik dan dengar pendapat (hearing) publik oleh Dewan Perwakilan Rakyat Daerah (DPRD) Kabupaten Ponorogo terkait dengan Perda tersebut. Dalam dengar pendapat disebutkan bahwa Perda tentang larangan TKI bercerai akan dijadikan sebagai salah satu pasal dalam Perda tentang Penempatan dan Perlindungan Tenaga Kerja Indonesia (TKI) Ponorogo. Perda ini juga rencananya akan mengatur tentang kejelasan pengasuhan anak yang bakal ditinggalkan oleh calon TKI. Perda yang lebih bernuansa pribadi TKI ini dijadwalkan akan terbit pada Juni 2015. ${ }^{7}$ Namun, hingga kini Perda tersebut belum disetujui dan diterbitkan. Padahal kini sudah berselang dua tahun dari sejak Perda tersebut digodok.

\footnotetext{
5 Pramita Kusumaningrum, "TKI Dominasi Angka Perceraian di Ponorogo", dalam http://beritajatim.com/hukum_kriminal/27278I/tki_dominasi_angka_perceraian_di_ponorogo.ht $\mathrm{ml}$, diakses tanggal 02 Februari 2017.

${ }^{6} \mathrm{lbid}$.
}

7 Dili Eyato, "DPRD Godog Perda TKI Dilarang Bercerai", dalam https://daerah.sindonews.com/read/984740/I 51/dprd-godok-perda-tki-dilarang-bercerai| 428026647 diakses tanggal 28 Januari 2017. 
Peraturan Daerah terakhir yang diterbitkan adalah Perda Provinsi Jawa Timur Nomor 04 Tahun 2016 tentang Pelayanan Penempatan dan Perlindungan Tenaga Kerja Indonesia ke Luar Negeri, ${ }^{8}$ namun di dalamnya belum terdapat pasal atau poin yang membahas tentang larangan perceraian bagi Tenaga Kerja Indonesia di luar negeri dan pasal yang mengatur tentang kejelasan pengasuhan anak yang akan ditinggalkan oleh calon TKI sebagaimana yang dimaksud sebelumnya.

Hukum Islam memiliki tujuan menciptakan kebahagiaan hidup manusia di dunia dan akhirat dengan cara mengambil segala yang bermanfaat dan mencegah atau menolak yang madharat yaitu yang tidak berguna bagi hidup dan kehidupan. Dengan kata lain, tujuan hukum Islam adalah kemaslahatan hidup manusia, baik rohani maupun jasmani, individual dan sosial, di dunia dan akhirat. Hal ini nampaknya berbanding terbalik dengan keadaan Tenaga Kerja Indonesia. Tujuan pertama warga Indonesia di antaranya warga Ponorogo berangkat ke luar negeri menjadi Tenaga Kerja Indonesia adalah untuk membentuk keluarga yang bahagia dengan taraf hidup yang meningkat dan sejahtera. Namun yang terjadi adalah sebaliknya, kebahagiaan keluarga tidak tercapai bahkan keluarga menjadi terpecah belah dengan terjadinya perceraian. Sementara bila tetap hidup di negara sendiri, kehidupan keluarga dijalani dengan pas-pasan bahkan kadangkala kurang.

Berdasarkan latar belakang di atas, penulis tertarik untuk mengkaji lebih dalam mengenai Raperda Kabupaten Ponorogo tentang Larangan Perceraian bagi Tenaga Kerja Indonesia (TKI) dilihat dari perspektif hukum Islam, khususnya dilihat dari segi urgensi, peluang dan tantangan dari implementasi Perda tersebut di lapangan.

\footnotetext{
${ }^{8}$ Lihat Peraturan Daerah Provinsi Jawa Timur nomor 4 tahun 2016 tentang Pelayanan Penempatan dan Perlindungan Tenaga Kerja Indonesia ke Luar Negeri, ditetapkan di Surabaya pada tanggal 23 Juni 2016 oleh Gubernur Jawa Timur.
} 


\section{Problematika Perceraian dalam Keluarga}

Sebagai makhluk sosial, manusia selalu membutuhkan orang lain untuk hidup. Karena itulah, manusia melakukan pernikahan atau perkawinan sebagai cara menjalin hubungan dengan orang lain lebih intim, membentuk keluarga dan melahirkan keturunan yang sah. Pernikahan merupakan akad/perjanjian yang kuat, bernilai ibadah. Terjadinya pernikahan menghasilkan hak dan kewajiban yang harus diterima dan dilaksanakan oleh suami dan istri. Hak dan kewajiban bersama antara suami dan istri dijelaskan dalam KHI pasal 77 yaitu: ${ }^{9}$

(a) Suami istri harus memikul kewajiban yang luhur untuk menegakkan rumah tangga yang sakinah, mawaddah dan rahmah yang menjadi sendi dari susunan masyarakat.

(b) Suami istri wajib saling mencintai, hormat menghormati, setia dan memberi bantuan lahir batin yang satu kepada yang lain.

(c) Suami istri memikul kewajiban untuk mengasuh dan memelihara anak-anak mereka, baik mengenai pertumbuhan jasmani, rohani maupun kecerdasan dan pendidikan agamanya.

(d) Suami istri wajib menjaga kehormatannya.

(e) Jika suami atau istri melalaikan kewajibannya, maka masingmasing dapat mengajukan gugatan kepada Pengadilan Agama.

(f) Suami istri harus mempunyai kediaman yang tetap.

(g) Rumah kediaman yang dimaksud dalam ayat (1) ditentukan suami istri bersama.

Sedangkan kewajiban suami yang menjadi hak istri disebutkan dalam KHI pasal 80 yaitu: a) memberi nafkah (makanan dan minuman), kiswah (pakaian) dan tempat kediaman bagi istri, b) biaya rumah tangga, biaya perawatan dan biaya pengobatan bagi istri dan anak, c) biaya pendidikan anak. Adapun terkait tempat tinggal disebutkan dalam KHI pasal 81 sebagai berikut:

(a) Suami wajib menyediakan tempat kediaman bagi istri dan anakanaknya atau bagi bekas istri yang masih dalam masa iddah.

9 Lihat Kompilasi Hukum Islam di Indonesia, Direktorat Pembinaan Peradilan agama Islam Ditjen Pembinaan Kelembagaan Islam Departemen Agama, 2001. 
(b) Tempat kediaman adalah tempat tinggal yang layak bagi istri selama dalam ikatan perkawinan atau dalam masa iddah talak atau iddah wafat.

(c) Tempat kediaman disediakan untuk melindungi istri dan anakanaknya dari gangguan pihak lain, sehingga mereka merasa aman dan tentram. Tempat kediaman juga berfungsi sebagai tempat menyimpan harta kekayaan, sebagai tempat menata dan mengatur alat-alat rumah tangga.

(d)Suami wajib melengkapi tempat kediaman sesuai dengan kemampuannya serta disesuaikan dengan keadaan lingkungan tempat tinggalnya, baik berupa alat perlengkapan rumah tangga maupun suatu penunjang lainnya.

Adapun kewajiban istri terhadap suami diatur dalam KHI pasal 83 sebagai berikut:

(a) Kewajiban utama bagi seorang istri adalah berbakti secara lahir batin kepada suami dalam batas-batas yang dibenarkan oleh hukum Islam.

(b) Istri menyelenggarakan dan mengatur keperluan rumah tangga sehari-hari dengan sebaik-baiknya.

Dalam Undang-Undang Nomor 1 Tahun 1974, disebutkan bahwa tujuan perkawinan adalah membentuk keluarga bahagia, sejahtera dan kekal berdasarkan Ketuhanan Yang Maha Esa,10 namun tidak semua perkawinan dapat berjalan mulus selaras tujuan awalnya. Banyak keluarga yang di tengah-tengah perjalanan bahtera rumah tangganya terjadi salah paham dan konflik yang tidak dapat dihindarkan, sehingga perceraian menjadi satu-satunya jalan yang harus diambil untuk mengakhiri hubungan yang telah dijalin dengan baik.

Perceraian merupakan ketetapan pemutusan ikatan lahir batin antara seorang pria dengan seorang wanita sebagai suami istri akibat gagalnya tujuan perkawinan karena perbuatan manusia. ${ }^{11}$

\footnotetext{
10 Undang-Undang Republik Indonesia Nomor I Tahun 1974 tentang Perkawinan.

"' Hilman Hadikusuma, Hukum Perkawinan Indonesia Menurut Perundangan, Hukum Adat, Hukum Agama Hindu-Islam, (Bandung: Mandar Maju, 1990), 160.
} 
Perceraian merupakan upaya untuk melepaskan ikatan suami istri dari suatu perkawinan yang disebabkan oleh alasan tertentu. Perceraian terjadi karena sudah tidak adanya jalan keluar (dissolution marriage). ${ }^{12}$ Ketetapan dan upaya ini merupakan perbuatan halal yang paling dibenci oleh Allah swt, sebagaimana sabda Nabi Muhammad saw "Abghadh al-halâl ilâ Allâh al-thalâq". ${ }^{13}$

Menurut Agus Dariyo, ada beberapa faktor penyebab perceraian, yaitu: ${ }^{14}$ (1) ketidaksetiaan salah satu pasangan hidup, (2) tekanan kebutuhan ekonomi keluarga, (3) tidak mempunyai keturunan, dan 4) perbedaan prinsip hidup dan agama. Sedangkan menurut Sulistyawati, faktor-faktor yang mempengaruhi perceraian adalah: (1) kurangnya kesiapan mental, (2) permasalahan ekonomi, (3) kurangnya komunikasi antar pasangan, (4) campur tangan keluarga pasangan, (5) perselingkuhan. ${ }^{15}$

Adapun dampak yang ditimbulkan dari perceraian sangat kompleks, baik bagi pasangan yang bercerai maupun bagi anak mereka. Walaupun di satu sisi perceraian dapat menyelesaikan masalah rumah tangga yang tidak mungkin lagi dikompromikan, namun perceraian juga menimbulkan dampak negatif berkaitan dengan pembangunan ekonomi rumah tangga, rusaknya hubungan individu dan sosial antar dua keluarga, dan yang lebih berat adalah perkembangan psikis anak mereka yang akan mempengaruhi perilakunya. Anak pada umumnya merasakan dampak psikologis, ekonomis dan koparental (pengasuhan anak) yang kurang menguntungkan dari orang tuanya. Kepribadian anak menjadi terbelah karena harus memilih salah satu orang tuanya. Memilih berpihak kepada ibunya berarti menolak ayahnya, begitu juga sebaliknya. ${ }^{16}$

\footnotetext{
12 Putri Novita Wijaya, "Faktor-Faktor yang Mempengaruhi Perceraian dalam Perkawinan" (Skripsi-Universitas Katolik Soegijapranata, Semarang, 2008), 23.

${ }^{13}$ Abu Dawud Sulaiman ibn Asy-as, Sunan Abi Dawud, Jilid II: 254, hadis nomor 2178, "Kitab atThalâq, Bab Kahariyah at-Thalâq", (Beirut: Dar al-Fikr, 1994).

${ }^{14}$ Agoes Dariyo, "Memahami Psikologi Perceraian dalam Keluarga", Jurnal Psikologi, Vol 2. No 2, 2004, 160.

${ }^{15}$ Putri Novita Wijaya, “Faktor-Faktor yang Mempengaruhi Perceraian dalam Perkawinan”, 23.

${ }^{16}$ T.O. Ihromi, Sosiologi Keluarga, (Jakarta: Yayasan Obor Indonesia, 2004), I6I.
} 
Menurut Dariyo dampak negatif perceraian yang biasanya dirasakan adalah ${ }^{17}$ : a) pengalaman traumatis pada salah satu pasangan hidup, b) ketidakstabilan dalam pekerjaan. Sedangkan menurut Wiran dan Sudarto, dampak yang ditimbulkan dengan adanya perceraian antara lain ${ }^{18}:$ a) adanya perasaan tersingkir dan kesepian, b) perasaan tertekan karena harus menyesuaikan diri dengan status baru sebagai janda/duda, c) permasalahan hak asuh anak, d) adanya masalah ekonomi, yaitu penurunan perekonomian secara drastis.

Dengan berbagai dampak yang dapat ditimbulkan dari perceraian tersebut, maka perceraian sesungguhnya tidak lebih maslahat dibandingkan dengan mempertahankan perkawinan yang masih bisa diperbaiki. Namun, apabila mempertahankan pernikahan akan menimbulkan dampak negatif dan perpecahan yang lebih luas, maka Islam memperbolehkan perceraian. ${ }^{19}$

\section{Regulasi Perceraian dalam Kompilasi Hukum Islam dan Hukum Nasional}

Perceraian merupakan salah satu faktor yang dapat menyebabkan putusnya hubungan pernikahan. ${ }^{20}$ Karena tujuan pernikahan adalah untuk membentuk keluarga yang bahagia, kekal dan sejahtera, maka Undang-Undang Nomor 1 Tahun 1974 tentang Perkawinan menganut prinsip mempersulit terjadinya perceraian. Berdasarkan hal tersebut, perceraian dalam Undang-Undang Perkawinan hanya dapat dilakukan di depan sidang Pengadilan Agama setelah Pengadilan Agama tersebut berusaha mendamaikan kedua belah pihak (mediasi). Bila mediasi gagal, maka dapat diteruskan ke proses perceraian.

\footnotetext{
${ }^{17}$ Agoes Dariyo, "Memahami Psikologi Perceraian dalam Keluarga"..., I 68.

18 Bety Wiyaswiyanti, "Dampak Psikologis Perceraian Pada Wanita" (Skripsi--Universitas Katolik Soegijapranata, Semarang, 2008), 37-38.

${ }^{19} \mathrm{Hal}$ ini sejalan dengan ayat al-Qur'an, surat al-Baqarah ayat 229.

20 Undang-Undang Republik Indonesia Nomor I Tahun 1974 tentang Perkawinan pasal 38 dan KHI pasal I I 3 menyebutkan: "Perkawinan dapat putus karena; a) kematian, b) perceraian, c) atas putusan pengadilan".
} 
Untuk mengajukan perceraian ke Pengadilan Agama, pihak yang mengajukan perceraian harus memiliki alasan-alasan yang cukup sesuai dengan yang telah ditentukan dalam Undang-Undang Perkawinan. Alasan cerai yang sah ditetapkan dalam penjelasan Pasal 39 Undang-Undang Nomor 1 Tahun 1974, Peraturan Pemerintah Nomor 9 Tahun 1975 Pasal 19 adalah sebagai berikut:

a) Salah satu pihak berbuat zina atau menjadi pemabuk, pemadat, penjudi dan lain sebaginya yang sukar disembuhkan;

b) Salah satu pihak meninggalkan pihak lain selama 2 (dua) tahun berturut-turut tanpa izin pihak lain dan tanpa alasan yang sah atau karena hal lain diluar kemampuannya;

c) salah satu pihak mendapat hukuman penjara 5 (lima) tahun atau hukuman yang lebih berat setelah perkawinan berlangsung;

d) Salah satu pihak melakukan kekejaman atau penganiayaan berat yang membahayakan pihak yang lain;

e) Salah satu pihak mendapat cacat badan atau penyakit dengan akibat tidak dapat mejalankan kewajibannya sebagai suami istri;

f) Antara suami dan istri terus menerus terjadi perselisihan dan pertengkaran dan tidak ada harapan akan hidup rukun lagi dalam rumah tangga.

Di samping alasan-alasan perceraian tersebut, Kompilasi Hukum Islam Pasal 116 menambahkan dua alasan lagi sebagai berikut:

a) Suami melanggar ta'lik talak. ${ }^{21}$

b) Peralihan agama atau murtad yang menyebabkan terjadinya ketidakrukunan dalam rumah tangga.

Berdasarkan pada alasan-alasan perceraian teresbut, bila Pengadilan Agama berpendapat alasan perceraian sebagaimana dijelaskan pada penjelasan ayat 2 dari Pasal 39 Undang-Undang Perkawinan jo Pasal 19 huruf (a-f) Peraturan Pemerintah Nomor 9 Tahun 1975 jo Pasal 116 KHI telah cukup, dan antara suami istri tersebut tidak mungkin lagi dapat didamaikan untuk hidup rukun

\footnotetext{
2l Ta'lik talak adalah janji atau pernyataan yang biasanya dibacakan dan ditanda-tangani suami sesaat setelah mengucapkan îjâb-qabûl pada waktu akad nikah.
} 
dalam rumah tangga (pasal $115 \mathrm{KHI}$ ), maka Pengadilan Agama akan mengadakan sidang untuk menyaksikan suami tersebut mengikrarkan talaknya kepada istrinya (pasal 6 Peraturan Pemerintah nomor 9 tahun 1975). Jadi ikrar talak diucapkan di depan sidang pengadilan di hadapan istri atau kuasanya. Berkenaan dengan cukupnya alasan perceraian harus juga diajukan alat bukti untuk meyakinkan hakim. Alat bukti dapat berupa surat, saksi, persangkaan, pengakuan dan sumpah sebagaimana disebutkan dalam pasal $164 \mathrm{HIR} /$ pasal $284 \mathrm{RBg} /$ pasal $1866 \mathrm{BW}$.

Bagi warga negara Indonesia yang berstatus Pegawai Negeri Sipil (PNS) dan yang dipersamakan ${ }^{22}$, memiliki aturan lain untuk melakukan perceraian selain poin-poin yang telah disebutkan di atas. PNS harus tunduk kepada Peraturan Pemerintah RI nomor 10 tahun 1983 tentang Izin Perkawinan dan Perceraian bagi Pegawai Negeri Sipil dan Peraturan Pemerintah RI nomor 45 tahun 1990 tentang Perubahan atas Peraturan pemerintah RI nomor 10 tahun 1983. Hal ini karena Pegawai Negeri Sipil sebagai abdi negara dan abdi masyarakat, diharapkan menjadi contoh dan teladan bagi bawahan dan masyarakat, sehingga Pegawai Negeri Sipil dibebani dengan ketentuan disiplin yang tinggi termasuk dalam perkawinan dan perceraian.

Dalam dua aturan tersebut disebutkan bahwa Pegawai Negeri Sipil yang akan melakukan perceraian wajib memperoleh izin atau surat keterangan lebih dahulu dari pejabat. Jika Pegawai Negeri Sipil berstatus sebagai "penggugat", maka ia wajib mendapatkan izin lebih dahulu dari pejabat sebelum melakukan perceraian. Permintaan izin perceraian diajukan oleh penggugat kepada pejabat secara tertulis melalui saluran hirarki. Akan tetapi, jika Pegawai

\footnotetext{
22 Pegawai Negeri Sipil dan yang dipersamakan dalam Peraturan Pemerintah Nomor 10 Tahun 1983 adalah meliputi selain Pegawai Negeri Sipil sebagaimana dimaksud dalam Undang-undang Nomor 8 tahun 1974 tentang Pokok-Pokok Kepegawaian termasuk juga pegawai Bulanan di samping pensiunan, Pegawai Bank Milik Negara, Pegawai Badan Usaha milik Negara, Pegawai Bank Milik Daerah, Pegawai Badan Usaha Milik Daerah, dan Kepala Desa, Perangkat Desa, serta petugas yang menyelenggarakan urusan pemerintahan di Desa. Lihat Peraturan Pemerintah Nomor 10 Tahun 1983 tentang Izin Perkawinan dan Perceraian Bagi Pegawai Negeri Sipil.
} 
Negeri Sipil berstatus sebagai "tergugat", maka ia wajib memperoleh surat keterangan lebih dahulu dari pejabat sebelum melakukan perceraian. Tergugat wajib memberitahukan adanya gugatan perceraian dari suami/istri secara tertulis melalui saluran hirarki dalam jangka waktu selambat-lambatnya enam hari kerja setelah menerima gugatan perceraian. ${ }^{23}$

Setiap atasan yang menerima permintaan izin perceraian dari Pegawai Negeri Sipil dalam lingkungannya, wajib memberikan pertimbangan dan meneruskannya kepada pejabat melalui saluran hirarki dalam jangka waktu selambat-lambatnya tiga bulan terhitung mulai tanggal ia menerima permintaan izin dimaksud. ${ }^{24}$ Sementara pemberian atau penolakan pemberian izin untuk melakukan perceraian harus dilakukan oleh pejabat secara tertulis dalam jangka waktu selambat-lambatnya tiga bulan terhitung mulai ia menerima permintaan izin dimaksud. ${ }^{25}$

Pejabat yang menerima permintaan izin perceraian wajib memperhatikan dengan seksama alasan-alasan permintaan izin dan pertimbangan dari atasan Pegawai Negeri Sipil yang bersangkutan. ${ }^{26}$ Jika alasannya kurang meyakinkan, maka pejabat tersebut harus meminta keterangan tambahan dari istri/suami Pegawai Negeri Sipil yang mengajukan permintaan izin atau dari pihak lain yang dipandang dapat memberikan keterangan yang

\footnotetext{
${ }^{23}$ Peraturan Pemerintah Nomor 45 Tahun 1990 pasal 3 ayat (I): "Pegawai Negeri Sipil yang akan melakukan perceraian wajib memperoleh izin atau surat keterangan lebih dahulu dari pejabat. Ayat (2) Bagi Pegawai negeri Sipil yang berkedudukan sebagai penggugat atau bagi pegawai negeri Sipil yang berkedudukan sebagai penggugat untuk memperoleh izin atau surat keterangan sebagaimana dimaksud dalam ayat (I) harus mengajukan permintaan secara tertulis. (3) Dalam surat permintaan izin atau pemberitahuan adanya gugatan perceraian untuk mendapatkan surat keterangan, harus dicantumkan alas an yang lengkap yang mendasarinya". Lihat Peraturan Pemerintah Nomor 45 Tahun 1990 tentang Perubahan Atas Peraturan Pemerintah nomor 10 tahun 1983 tentang Izin Perkawinan dan Perceraian bagi Pegawai Negeri Sipil.

${ }^{24}$ Peraturan Pemerintah Nomor 45 Tahun 1990 pasal 5 ayat (2).

${ }^{25}$ Peraturan Pemerintah Nomor 10 Tahun 1983 pasal 13.

${ }^{26}$ Peraturan Pemerintah Nomor 10 tahun 1983 pasal 6 ayat (I). Penting diperhatikan bahwa: "Izin untuk bercerai karena alasan isteri mendapat cacat bawaan atau penyakit dengan akibat tidak dapat menjalankan kewajibannya sebagai isteri, tidak diberikan oleh pejabat." Hal ini diatur dalam Peraturan Pemerintah Nomor 10 tahun 1983 pasal 7 ayat (2)
} 
meyakinkan. ${ }^{27}$ Pada prinsipnya, pejabat tersebut harus berusaha lebih dahulu merukunkan mereka kembali dengan cara memanggil dan menasehati mereka secara langsung, sebelum mengambil keputusan. ${ }^{28}$

Di samping beberapa peraturan di atas, ada juga Peraturan Mahkamah Agung nomor 1 tahun 2008 tentang Pelaksanaan Mediasi di Pengadilan. Dalam Perma ini disebutkan bahwa setiap perkara perdata termasuk perceraian harus terlebih dahulu dimediasikan agar para pihak dapat diupayakan bersatu kembali. Upaya mediasi ini dilakukan maksimal 40 hari setelah gugatan diajukan. Apabila upaya mediasi gagal, maka dilanjurkan ke sidang pengadilan.

Selama ini, kendala yang dihadapi dalam upaya mediasi Tenaga Kerja Indonesia (TKI) adalah pihak TKI tidak dapat hadir karena masih berada di luar negeri, sehingga upaya mediasi hanya diwakilkan kepada pengacara. Dalam sidang pengadilan hukum acara perdata, baik di Pengadilan Agama maupun Pengadilan Negeri, memberikan peluang terhadap para pihak untuk saling menjawab dan mengajukan alat bukti. Dengan demikian, ketika salah satu pihak menyetujui atau keberatan atas gugatan perceraian dapat meyakinkan hakim dengan membawa alat bukti.

Dari beragam peraturan yang telah disebutkan di atas, belum ada peraturan yang terbukti ampuh meminimalisasi perceraian. Walaupun dikatakan bahwa peraturan-peraturan tersebut memiliki prinsip mempersulit terjadinya perceraian, namun aturan-aturan lain dapat diakali dan dibuat mudah. Sebagaimana aturan tentang dapat diwakilkannya para pihak kepada pengacara. Hal ini banyak dimanfaatkan oleh para Tenaga Kerja Indonesia (TKI) yang sedang berada di luar negeri.

\footnotetext{
${ }^{27}$ Peraturan Pemerintah Nomor 10 tahun 1983 pasal 6 ayat (2).

${ }^{28}$ Peraturan Pemerintah Nomor 10 tahun 1983 pasal 6 ayat (3).
} 


\section{Pengertian Tenaga Kerja Indonesia dan Tenaga Kerja Wanita}

Tenaga Kerja Indonesia (TKI) merupakan sebutan bagi warga negara Indonesia yang bekerja di luar negeri dalam hubungan kerja untuk jangka waktu tertentu dengan menerima upah. Istilah ini digunakan untuk menunjuk pada buruh migran yang mempersonifikasikan identitas regional kenegaraan. Ini membuktikan bahwa buruh di manapun berada adalah warga negara Indonesia. Sedangkan bagi TKI berjenis kelamin wanita, dikenal dengan istilah tenaga kerja wanita (TKW). Selama ini, istilah TKI/TKW sering dikonotasikan sebagai pekerja kasar.

Ada beberapa pendapat mengenai pengertian Tenaga Kerja Indonesia. Menurut Pasal 1 bagian (1) Undang-Undang Nomor 39 Tahun 2004 tentang Penempatan dan Perlindungan Tenaga Kerja Indonesia di Luar Negeri, TKI adalah setiap warga negara Indonesia yang memenuhi syarat untuk bekerja di luar negeri dalam hubungan kerja untuk jangka waktu tertentu dengan menerima upah. Menurut Yudo, tenaga kerja wanita (TKW) adalah tiap wanita yang mampu melakukan pekerjaan, baik di dalam maupun di luar hubungan kerja, guna menghasilkan barang atau jasa, untuk memenuhi kebutuhan masyarakat. ${ }^{29}$

Ketika menjadi tenaga kerja di luar negeri, hubungan kerja yang terjadi dalam pengertian ekonomi dalam dua sektor, yaitu sektro formal dan sektor non formal. Yang dimaksud dengan sektor formal adalah suatu pekerjaan yang dilakukan dalam perjanjian kerja dalam usaha yang berbeda hukum dengan segala syarat kerja, upah, serta hak dan kewajiban kerja telah ada dan ditetapkan untuk semua pekerjaa secara jelas. Sedangkan yang dimaksud dengan pekerja pada pekerjaan sektor non formal pekerjaan yang diberikan kepada tenaga kerja adalah pengguna jasa perorangan.

Adapun tipologi Tenaga Kerja Indonesia dibagi menjadi dua yaitu mereka yang bermigrasi secara legal dan yang bermigrasi

\footnotetext{
${ }^{29}$ Janeko, "Fenomena Pereceraian di Kalangan Tenaga Kerja Wanita (TKW) Hongkong dan Taiwan: Studi di Desa Kedungsalam, Kecamatan Donomulyo, Kabupaten Malang" (Skripsi-Universitas Islam Negeri Maulana Malik Ibrahim Malang, 20 I I), I3.
} 
secara ilegal. Migrasi ke luar negeri disebut legal sepanjang memenuhi ketentuan administrasi yang ditetapkan sehingga datang ke negara lain karena telah dilengkapi dokumen yang diharuskan. Sedangkan sebagai tenaga kerja yang pergi ke luar negeri tanpa dilengkapi dokumen yang sah maka disebut sebagai TKI ilegal. Saat ini pengiriman tenaga kerja legal ditangani oleh pemerintah bersama-sama dengan perusahaan pengerah tenaga kerja. Untuk melaksanakan penempatan jasa tenaga kerja, dikoordinir oleh Departemen Tenaga Kerja dan Transmigrasi melalui Lembaga Antar Kerja Antar Negara. Pelaksanaan pengiriman tenaga kerja dilaksanakan oleh Perusahaan Pengiriman Jasa Tenaga Kerja Indonesia (PJTKI). ${ }^{30}$

Banyak faktor yang menjadi alasan kuat warga negara Indonesia tertarik ataupun terdorong untuk menjadi Tenaga Kerja di luar negeri meninggalkan keluarga di tanah air. Beberapa faktor penarik menjadi TKW adalah adanya ajakan dari saudara, teman, dan kerabat migran yang terlebih dahulu melakukan migrasi ke luar negeri. Kondisi bekerja di luar negeri dilihat lebih menguntungkan bila dibandingkan dengan kondisi bekerja di daerah asal mereka, yaitu gaji yang tinggi dan peluang kerja yang luas. Di sisi lain menunjukkan bahwa tidak ada faktor rintangan yang menghambat mereka untuk melakukan migrasi ke luar negeri baik dari faktor jarak, biaya, maupun keluarga, dan terakhir adalah faktor pribadi yaitu secara pribadi memutuskan untuk bermigrasi dan bekerja ke luar negeri karena ingin hidup mandiri serta tidak bergantung pada orang lain dan semata-mata demi masa depan keluarga. ${ }^{31}$

Adapun faktor pendorong menjadi TKW adalah kurangnya lapangan pekerjaan di daerah asal, penurunan lahan pertanian, tuntutan ekonomi rumah tangga yang tinggi dan penurunan tingkat upah. Jika dilihat dari pembagian kerja secara gender,

\footnotetext{
${ }^{30}$ Arif Nasution M, Globalisasi dan Migrasi Antar Negara, (Bandung: Alumni, 1999), 4.

3! Nanda Putri Riyani, "Analisis Pengaruh Keterlibatan Ayah dalam Pengasuhan terhadap Pencapaian Pendidikan Anak di Keluarga Migran" (Skripsi--Institut Pertanian Bogor, 20 I 5).
} 
perempuan hanya sebagai pemegang sektor domestik di dalam keluarga. Namun karena hal itu, perempuan menjadi mempunyai tanggung jawab terhadap kesejahteraan keluarga. Perempuan yang merasa bertanggung jawab terhadap kesejahteraan keluarga akhirnya menjadi terpaksa ambil bagian untuk meningkatkan pendapatan keluarga.

\section{Konstruk Sosial-Budaya Kabupaten Ponorogo}

Secara geografis, Kabupaten Ponorogo terletak di wilayah barat Provinsi Jawa Timur dengan luas wilayah 1.371,78 km2 yang secara administratif terbagi dalam 21 Kecamatan dan 307 Desa/Kelurahan. Kabupaten Ponorogo terletak antara $111^{\circ} 17^{\prime}-111^{\circ}$ 52' Bujur Timur (BT) dan $7^{\circ} 49^{\prime}-8^{\circ} 20^{\prime}$ Lintang Selatan (LS) dengan ketinggian antara $92-2.563$ meter di atas permukaan laut yang dibagi menjadi 2 sub area yaitu area dataran tinggi yang meliputi Kecamatan Ngrayun, Sooko, Pudak, Ngebel dan 17 kecamatan lainnya merupakan daerah daratan rendah. Sungai yang melewati ada 14 sungai dengan panjang antara 4 sampai dengan $58 \mathrm{Km}$ sebagai sumber irigasi bagi lahan pertanian dengan produksi padi maupun hortikultura. Sebagian besar dari luas yang ada terdiri dari area kehutanan dan lahan sawah, sedang sisanya digunakan untuk tegal, pekarangan dan lainnya. Luas wilayah Kabupaten Ponorogo adalah 1.371,78 Km2. Secara topografi dikelilingi barisan pegunungan yang bersambung mulai dari Gunung Wilis di sebelah timur membentang ke arah selatan dan berakhir pada Gunung Lawu di sebelah barat.

Jarak ibu kota Kabupaten Ponorogo dengan ibu kota Provinsi Jawa Timur (Surabaya) kurang lebih $200 \mathrm{~km}$ ke arah timur laut dan jarak dengan ibukota negara (Jakarta) $800 \mathrm{~km}$ ke arah barat. Adapun batas-batas wilayah Kabupaten Ponorogo adalah sebagai berikut:

( ) Sebelah Utara: Kabupaten Madiun, Kabupaten Magetan, Kabupaten Nganjuk

๑) Sebelah Timur: Kabupaten Tulungagung, Kabupaten Trenggalek

๑) Sebelah Selatan: Kabupaten Pacitan 
(2) Sebelah Barat: Kabupaten Pacitan, Kabupaten Wonogiri (Provinsi Jawa Tengah)

Jumlah penduduk di Kabupaten Ponorogo sebanyak 445.601 jiwa laki-laki dan 450.320 jiwa perempuan. Untuk menjalankan roda pemerintahan, Pemerintah Kabupaten Ponorogo didukung oleh 12.379 Pegawai Negeri Sipil (Daerah Dalam Angka 2010 - BPS). Menurut hasil Survei Sosial Ekonomi Nasional Tahun 2008 penduduk Kabupaten Ponorogo pada akhir tahun 2008 mengalami perkembangan sebesar 0,52 persen. Secara keseluruhan penduduk wanita sedikit lebih banyak bila dibanding penduduk pria. Sex Ratio atau perbandingan jumlah penduduk per 100 penduduk perempuan akhir tahun 2008 menunjukkan penurunan, yaitu dari 101,30 persen pada akhir tahun 2007 menjadi 98,95 persen, yang berarti di Kabupaten Ponorogo penduduk perempuannya lebih banyak dibanding penduduk pria di mana setiap 100 penduduk perempuan terdapat 99 penduduk pria (Daerah Dalam Angka 2010 - BPS).

Secara administratif, wilayah Kabupaten Ponorogo terbagi menjadi 21 kecamatan, 307 desa/kelurahan, 947 dusun/lingkungan. Kecamatan yang ada di Kabupaten Ponorogo adalah Ngrayun, Slahun, Bungkal, Sambit, Sawoo, Sooko, Pudak, Pulung, Mlarak, Siman, Jetis, Balong, Kauman, Jambon, Badegan, Sampung, Sukorejo, Ponorogo, Babadan, Jenangan, dan Ngebel. Untuk menjalankan roda pemerintahan didukung oleh segenap pegawai ditingkat Kabupaten sampai desa/kelurahan.

\section{Fenomena Perceraian Tenaga Kerja Indonesia di Kabupaten Ponorogo}

Menurut penuturan Kepala Desa Jambon dan Blembem, Ponorogo, niat awal yang mendorong para warga Ponorogo berangkat ke luar negeri untuk bekerja sebagai Tenaga Kerja Indonesia terutama TKW adalah untuk memenuhi dan meningkatkan taraf kehidupan keluarga hingga keluarga menjadi bahagia. Mayoritas yang berangkat ke luar negeri adalah istri, karena peluang lowongan pekerjaan dan gaji tinggi lebih banyak 
membutuhkan tenaga kerja wanita. Mereka pergi mencari nafkah ke luar negeri dengan meninggalkan tanggung jawab anak kepada suami.

Namun niat awal ini ternyata tidak sepenuhnya menjadi kenyataan karena banyak faktor yang melatarbelakanginya hingga akhirnya menjadikan suami atau istri memutuskan untuk bercerai. Perceraian merupakan suatu proses yang di dalamnya menyangkut banyak aspek seperti: emosi, ekonomi, sosial, dan pengakuan secara resmi oleh masyarakat melalui hukum yang berlaku.

Ada banyak faktor yang menjadi penyebab perceraian pada keluarga Tenaga Kerja Indonesia, yaitu faktor intern dan faktor ekstern. Faktor intern meliputi:

1) Ekonomi atau keuangan keluarga

Setelah bekerja di luar negeri, banyak dari TKI mendapatkan gaji yang tinggi. Penghasilan tinggi menjadikan mereka sebagai tulang punggung keluarga. Keadaan yang demikian membentuk kesenjangan penghasilan antara suami dan istri yang lambat laun menjadi masalah cukup serius. Istri merasa memberikan pemasukan lebih tinggi terhadap rumah tangga dibandingkan suami, sehingga merasa dapat hidup mandiri karena ekonomi yang tercukupi.

2) Tidak ada tanggung jawab

Pernikahan membuat suami dan istri mempunyai kewajiban dan tanggung jawab yang harus dilaksanakan. Semua masalah yang timbul menjadi tanggung jawab suami dan istri, namun jika suami/istri dianggap tidak bertanggung jawab melaksanakan kewajibannya, menyebabkan pasangan menuntut perceraian, karena merasa hak-haknya sudah tidak terpenuhi lagi. Adakalanya suami kurang bertanggung jawab dalam hal keuangan dengan menggunakan uang kiriman dari istri untuk bersenang-senang. Istri akhirnya mengirimkan uang kepada orang tua atau saudara yang lebih dipercaya dapat menyimpan uang tersebut. Hal ini menyebabkan konflik antara suami dan istri. 
3) Kurangnya komunikasi antar pasangan

Banyak keluarga TKI yang mengalami kurang komunikasi, hingga menyebabkan mereka serasa jauh. Komunikasi yang tidak dapat berjalan dengan baik tersebut menyebabkan perselisihan yang berdampak pada ketidakharmonisan keluarga dan perceraian.

Adapun faktor ekstern yang menjadi penyebab perceraian, antara lain:

a) Campur tangan pihak lain

Adanya campur tangan pihak keluarga membuat salah satu pihak merasa kurang dihargai dan merasa tidak nyaman dengan pasangannya sehingga akan menimbulkan perselisihan atau konflik dalam rumah tangga, ketika hal tersebut sudah tidak dapat ditoleransi lagi hingga terjadi perceraian.

b) Ketidaksetiaan atau perselingkuhan

Ketidaksetiaan atau perselingkuhan adalah faktor yang seringkali terjadi di keluarga TKI. Adakalanya suami yang berselingkuh ketika ditinggal oleh istri bekerja di luar negeri. Kadangkala istri yang berselingkuh karena tertarik dengan sesama Tenaga Kerja Indonesia yang lain, padahal suami di rumah bertanggung jawab dan mengurus anak dengan sungguh-sungguh.

Mayoritas perceraian yang diajukan oleh Tenaga Kerja Indonesia di Ponorogo melalui pengacara. Hal ini karena ada aturan yang tidak mengharuskan para pihak hadir dalam proses persidangan dan mudahnya proses perceraian dengan menyerahkan kasus kepada pengacara. Sementara komunikasi yang terjadi antara TKI dengan pasangan dalam hal memberitahukan tentang keinginan bercerai hanya menggunakan send message service (sms). Kebanyakan model perceraian ini terjadi pada TKI yang sudah berkali-kali berangkat ke luar negeri dan pada usia-usia produktif, sehingga membuat pola pemikiran mereka berubah dari niat awalnya. ${ }^{32}$

32 Yatemun dan Djimanto, Ponorogo, Wawancara, Ponorogo, 28 September 2016. 


\section{Substansi Raperda di Kabupaten Ponorogo}

Tenaga Kerja Indonesia dilindungi dengan berbagai peraturan hukum, baik yang berupa Undang-Undang, Peraturan Pemerintah, Peraturan Presiden, Peraturan Menteri, Peraturan Kepala BNP2TKI, bahkan Peraturan Daerah. Mayoritas dari peraturan hukum tersebut menyangkut tentang penempatan, perlindungan, hak-hak dan kewajiban Tenaga Kerja Indonesia. ${ }^{33}$

Di antara Undang-Undang tersebut adalah Undang-Undang Nomor 39 Tahun 2004 tentang Penempatan dan Perlindungan Tenaga Kerja Indonesia, Undang-Undang Nomor 06 Tahun 2012 tentang Pengesahan Konvensi Internasional mengenai Perlindungan Hak-hak Seluruh Pekerja Migran dan Anggota Keluarganya, dan Undang-Undang Nomor 39 Tahun 1999 tentang Hak Asasi Manusia. Adapun Peraturan Pemerintah yang ada antara lain: Peraturan Pemerintah Nomor 03 Tahun 2013 tentang Perlindungan Tenaga Kerja Indonesia di Luar Negeri, Peraturan Pemerintah Nomor 04 Tahun 2013 tentang Tata Cara Pelaksanaan Penempatan Tenaga Kerja Indonesia di Luar Negeri oleh Pemerintah, dan Peraturan Pemerintah Nomor 05 Tahun 2013 tentang Tata Cara Penilaian dan Penetapan Mitra Usaha dan Pengguna Perseorangan.

Sementara Peraturan Presiden yang terkait dengan Tenaga Kerja Indonesia di antaranya Perpres Nomor 81 Tahun 2006 tentang Badan Nasional Penempatan dan Perlindungan Tenaga Kerja Indonesia, Perpres Nomor 64 Tahun 2001 tentang Pemeriksaan Kesehatan dan Psikologi Calon Tenaga Kerja Indonesia, dan Perpres Nomor 45 Tahun 2013 tentang Koordinasi Pemulangan Tenaga Kerja Indonesia. Sedangkan beberapa peraturan terbaru dikeluarkan oleh Kepala BNP2TKI di antaranya Perka BNP2TKI Nomor 04 Tahun 2017 tentang Pemberdayaan TKI, TKI Purna, dan Keluarganya.

33 Lihat produk hukum terkait Tenaga Kerja Indonesia di http://jdih.bnp2tki.go.id/index.php?option =com_content\&view =article\&id =38\&ltemid =7 I $8 \& \mathrm{la}$ ng=en. diakses tanggal I 5 Maret 2017. 
Peraturan Daerah terakhir yang dikeluarkan oleh Provinsi Jawa Timur adalah Peraturan Daerah Provinsi Jawa Timur Nomor 4 Tahun 2016 Tentang Pelayanan Penempatan dan Perlindungan Tenaga Kerja Indonesia ke Luar Negeri. Dalam peraturan yang ditetapkan di Surabaya pada tanggal 23 Juni 2016 oleh Gubernur Jawa Timur tersebut, belum terdapat pasal atau poin yang membahas tentang larangan perceraian bagi Tenaga Kerja Indonesia di luar negeri.

Dalam rapat acara gelar uji publik dan dengar pendapat (hearing) publik oleh Dewan Perwakilan Rakyat Daerah (DPRD) Kabupaten Ponorogo pada tanggal 3 April 2015 terkait dengan Perda tersebut, dijelaskan bahwa Perda tentang larangan TKI bercerai akan dijadikan sebagai salah satu pasal dalam Perda tentang Penempatan dan Perlindungan Tenaga Kerja Indonesia (TKI) Ponorogo. Dalam pasal tersebut akan dibahas tentang warga Ponorogo yang bekerja di luar negeri sebagai TKI dilarang bercerai. Pasangan yang salah satu atau keduanya merantau ke negeri orang wajib mempertahankan pernikahannya sampai masa kerjanya selesai dan kembali lagi ke tanah air. Pasangan yang salah satu atau keduanya berangkat menjadi TKI wajib membuat komitmen secara lisan hingga tertulis untuk tidak bercerai.

Komitmen tersebut, baik lisan maupun tertulis, akan dijadikan syarat untuk berangkat ke luar negeri menjadi TKI. Komitmen tersebut dituangkan dalam surat pernyataan tidak melakukan perceraian selama bekerja di luar negeri. Hal ini akan diatur oleh salah satu pasal dalam Raperda tentang larangan perceraian TKI. Pasal-pasal yang terdapat dalam Perda tersebut dibuat berdasarkan pertimbangan tingginya angka perceraian di Ponorogo yang tiap tahun meningkat. Aturan ini diharapkan dapat melindungi TKI dari perpecahan keluarga.

Di samping pasal yang mengatur tentang larangan perceraian bagi TKI selama bekerja di luar negeri, pasal dalam Perda ini rencananya juga akan mengatur tentang kejelasan pengasuhan anak yang akan ditinggalkan oleh calon TKI. Pasal ini menghendaki 
penunjukan secara tertulis orang-orang yang akan bertanggung jawab terhadap pengasuhan dan perkembangan anak calon TKI. ${ }^{34}$ Mengingat banyak kasus tentang penelantaran dan kekerasan anak TKI yang disebabkan ketidakjelasan pengasuhan, kurangnya kasih sayang dan perhatian.

Dua pasal yang telah disebutkan di atas, yaitu larangan perceraian bagi TKI selama bekerja di luar negeri dan kejelasan pengasuhan anak TKI merupakan ranah pribadi perseorangan dan bukan merupakan ranah pemerintah daerah. Namun demikian, ranah pribadi tersebut telah berimbas pada ranah pemerintahan, sehingga sudah seharusnya diatur.

Larangan perceraian bagi TKI selama bekerja di luar negeri dan kejelasan pengasuhan anak TKI pada dasarnya tidak memiliki dasar hukum. Namun, mengingat banyaknya kasus perceraian dan penelantaran anak TKI menjadikan hal tersebut kritis dan urgen untuk segera direspon Pemerintah.

Hal ini dikuatkan juga dengan tanggapan para tokoh masyarakat Ponorogo, di antaranya Kepala Desa Jambon (Yatemun) $^{35}$ dan Kepala Desa Blembem (Djimanto) ${ }^{36}$ terkait perlu dan pentingnya Perda yang mengatur tentang larangan perceraian bagi TKI dan pengasuhan anak. Dalam tanggapannya, dua tokoh tersebut sama-sama berpendapat perlu adanya Perda yang membahas tentang kesepakatan TKI dan pasangannya untuk tidak bercerai, saling amanah dan percaya. Kesepakatan tersebut harus juga diketahui oleh minimal Kepala Desa. Setelah berhasil, TKI harus kembali ke tanah air. Selain itu, terkait pengasuhan anak, perlu juga ada pasal yang mengatur tentang ibu tidak boleh menjadi

\footnotetext{
34 Dili Eyato, "DPRD Godog Perda TKI Dilarang Bercerai", dalam https://daerah.sindonews.com/read/984740// 5 I/dprd-godok-perda-tki-dilarang-bercerai| 428026647 diakses tanggal 28 Januari 2017.

35 Yatemun, Kepala Desa Jambon, Ponorogo, Wawancara, Kantor Kepala Desa Jambon, 28 September 2016.

${ }^{36}$ Djimanto, Kepala Desa Blemben, Ponorogo, Wawncara, Kantor Kepala Desa Blembem, 28 September 2016.
} 
TKW sebelum usia anak genap 2 tahun. Setelah usia anak 2 tahun lebih, maka harus ada kejelasan tentang pengasuhnya.

Tanggapan tersebut selaras dengan adanya Rancangan Peraturan Daerah terkait dengan larangan perceraian bagi TKI di luar negeri dan kejelasan pengasuhan anak. Meskipun bukan merupakan ranah publik, namun terdapat pesan sosial dan moral yang sangat kritis dan urgen di dalamnya.

\section{Raperda dalam Perspektif Hukum Islam}

Perkawinan atau pernikahan merupakan akad yang sangat kuat atau mîtsâqan ghalîdzan untuk menaati perintah Allah dan melaksanakannya bernilai ibadah. ${ }^{37}$ Dalam kata lain, perkawinan merupakan suatu akad atau perjanjian untuk mengikatkan diri antara seorang laki-laki dan wanita untuk menghalalkan hubungan kelamin antara kedua belah pihak dengan dasar sukarela dan keridlaan kedua belah pihak untuk mewujudkan suatu kebahagiaan hidup berkeluarga yang diliputi rasa kasih sayang dan ketentraman dengan cara-cara yang diridlai oleh Allah swt. ${ }^{38}$ Dengan demikian, pernikahan bukan hanya kontrak sosial atau keperdataan biasa, tapi ikatan pernjanjian yang suci dan bernilai ibadah. Tujuan dari pernikahan adalah membentuk keluarga (rumah tangga) yang bahagia dan kekal berdasarkan Ketuhanan Yang Maha Esa. ${ }^{39}$

Dalam perjalanannya, tidak semua rumah tangga dapat berakhir sampai kematian suami istri. Seringkali ketidakmampuan pasangan dalam memenuhi kewajiban dan tidak mendapatkan hak dari pasangan menjadi konflik yang luar biasa dalam rumah tangga. Hal ini menyebabkan terjadinya perceraian.

Ponorogo sebagai salah satu pemasok Tenaga Kerja Indonesia yang besar di Provinsi Jawa Timur mengalami peningkatan yang terus berlanjut dalam hal angka perceraian hingga dalam tingkat

\footnotetext{
${ }^{37}$ Ahmad Rofiq, Hukum Islam di Indonesia, (Jakarta: PT. Raja Grafindo Persada, 1995), 60.

38 Ahmad Azhar Basyir, Hukum Perkawinan Islam, (Yogyakarta: Bagian Penerbitan Fak. Hukum Universitas Islam Indonesia, 1977), 10.

${ }^{39}$ Sastroatmojo, Hukum Perkawinan di Indonesia, (Jakarta: Bulan Bintang, 1990), 80.
} 
yang meresahkan. Perceraian tersebut mayoritas terjadi di kalangan Tenaga Kerja Indonesia yang seharusnya sesuai niat awal ke luar negeri untuk meningkatkan taraf kehidupan dan kebahagiaan rumah tangga, namun ternyata kenyataan yang terjadi adalah sebaliknya.

Banyak faktor yang menjadi penyebab terjadinya perceraian TKI. Mulai dari faktor ekonomi, tidak ada tanggung jawab, kurangnya komunikasi, gaya hidup, campur tangan pihak lain, serta perselingkuhan. Untuk mencegah peningkatan angka perceraian di Ponorogo, Pemerintah Daerah Kabupaten Ponorogo menggodok Rancangan Peraturan Daerah yang melarang TKI bercerai ketika di luar negeri, namun hingga saat ini belum disahkan dan ditetapkan. Padahal dari segi urgensinya, Perda tersebut sangat dibutuhkan.

Pada dasarnya sudah ada peraturan yang mengatur tentang perceraian diantaranya Undang-Undang Nomor 1 Tahun 1974 tentang Perkawinan, Peraturan Pemerintah Nomor 9 Tahun 1975 tentang Pelaksanaan Undang-Undang Nomor 1 Tahun 1974 tentang Perkawinan dan Peraturan Mahkamah Agung Nomor 1 Tahun 2008 tentang Prosedur Mediasi di Pengadilan. Peraturan-peraturan tersebut menganut prinsip mempersulit perceraian. Namun ternyata peraturan tersebut tidak cukup kuat untuk mencegah dan meminimalisasi terjadinya perceraian, melihat terus meningkatnya angka perceraian di Indonesia.

Kondisi yang demikian (tidak segera disahkan dan ditetapkannya Peraturan Daerah yang melarang TKI bercerai) bertentangan dengan tujuan hukum Islam yaitu mewujudkan kemaslahatan umat manusia. Kemaslahatan umat sejalan dengan maqâshid al-syarî'ah (tujuan syariat agama) yang terumuskan dalam kulliyât al-khams, yaitu: hifzh al-dîn (melindungi agama), hifzh al-nafs (melindungi jiwa), hifzh al-'aql (melindungi akal), hifzh al-nasab (melindungi keturunan) dan hifzh al-mâl (melindungi kekayaan). Segala perilaku yang mengarah kepada kemudharatan atau kemafsadatan semakna dengan perbuatan mengancam agama, 
jiwa, akal, nasab, dan harta. ${ }^{40}$ Urgensi Peraturan Daerah tentang larangan bagi TKI bercerai masuk dalam ranah kemaslahatan umat yaitu menjaga agama, jiwa, akal, keturunan dan kekayaan. Dengan demikian, seharusnya Peraturan Daerah tersebut harus segera disahkan dan ditetapkan. Setelah ditetapkan, Perda tersebut dapat segera diimplementasikan sehingga perceraian dapat dicegah atau diminimalisasi.

Keberadaan Peraturan Daerah tentang larangan perceraian bagi Tenaga Kerja Indonesia sejalan dengan kaidah ushul fiqh yang telah dirumuskan oleh para fuqaha yang berbasis kemaslahatan, sebagaimana idealisme ajaran agama Islam. Idealisme tersebut dibingkai dalam epistemologi maqâshid al-syarî'ah. Atas dasar pemikiran kemaslahatan, maka keberadaan Peraturan Daerah terkait larangan perceraian Tenaga Kerja Indonesia sangat penting dan urgen. Hal ini dikuatkan dengan kaidah ushul fikih, antara lain: 1. Kaidah ketiga puluh empat (dari 68 kaidah tambahan dalam alMajallat al-Ahkâm al-'Adliyyah)

"Al-hukm yattabi' al-mashlahah al-râjihah"

"Hukum itu mengikuti kemaslahatan yang paling kuat/banyak." ${ }^{41}$

2. Kaidah Keenam puluh Tujuh (dari 68 kaidah tambahan dalam Al-Majallât al-Ahkâm al-Adliyyah)

"Yuqaddim fì kull wilâyah man huwa aqdam alâ al-qiyâm bi huqûqihâ wa mashâlihihâ"

"Orang-orang yang lebih berani menegakkan hak-hak dan kemaslahatan-kemaslahatan harus didahulukan pada setiap kekuasaan." 42

Dengan kajian ushul fikih di atas, alangkah baiknya bila Rancangan Peraturan Daerah tentang larangan perceraian bagi Tenaga Kerja Indonesia atau tenaga kerja wanita segera disahkan dan diterbitkan. Dengan demikian, Perda tersebut dapat diberlakukan dan dampak positifnya segera dirasakan oleh masyarakat. Melihat kondisi perceraian yang semakin lama

\footnotetext{
${ }^{40}$ Yusuf al-Qardhawi, Ri'âyah al-Bîah fî al-Syarîah al-Islâmiyyah, (Kairo: Dar al-Syuruq, 200 I), 44.

${ }^{41}$ Asjmuni A. Rahman, Qoidah-Qoidah Figh, (Jakarta: Bulan Bintang, 1976), 71.

42 lbid., 139.
} 
semakin bertambah dan menjadi tren bagi masyarakat, khususnya Tenaga Kerja Indonesia. Bila pencegahan dapat dilakukan sesegera mungkin, maka akan lebih baik.

Peluang Peraturan Daerah tersebut dalam mencegah dan meminimalisasi angka perceraian di Ponorogo sangat besar. Pasalnya dalam Perda tersebut menyebutkan bahwa TKI dilarang bercerai ketika terikat kontrak di luar negeri. Bila bermaksud bercerai, maka yang bersangkutan harus sudah rampung kontrak kerjanya dan berada di Indonesia. Dengan demikian, dalam upaya mediasi diharapkan yang bersangkutan dapat hadir, sehingga peluang berhasilnya upaya mediasi lebih banyak. Sebenarnya Perda TKI ini akan lebih baik bila didampingi dengan peraturan yang tidak membolehkan yang berpekara absen dari upaya mediasi atau tidak melimpahkan kepada pengacara. Dengan harapan, upaya untuk kembali bersama lebih besar.

Upaya penyuluhan juga sebaiknya dilakukan oleh Pemerintah Daerah, baik pra maupun pasca pemberangkatan TKI ke luar negeri, sebagai cara selain peraturan. Upaya penyuluhan pra pemberangkan dilakukan dengan cara menanamkan pada diri TKI dan keluarga bahwa perkawinan adalah komitmen yang mulia dan agung, memastikan bahwa pasangan dan keluarga mereka adalah prioritas utama dalam hidup, menjaga komunikasi dengan pasangan dan mengesampingkan ego pribadi. Sedangkan upaya penyuluhan pasca pemberangkatan adalah dengan mencari sumber permasalahan ketika terjadi konflik dan berupaya mencari penyelesaian sebaik-baiknya, selalu introspeksi diri, tidak membesarkan masalah, menjalin komunikasi dengan baik, dan mengingat anak sebagai objek yang akan mendapatkan dampak yang paling besar apabila terjadi perceraian.

Dengan mengedepankan kemaslahatan yang lebih besar (almashlahah al-mu'azhzham) dibanding dengan maslahat yang lebih kecil, dan dengan berdasarkan tujuan tasyri' yakni jalb al-mashâlih wa dar' al-mafâsid, maka seharusnya angka perceraian di Ponorogo dapat diminimalisasi. Bila ini berhasil, dapat dijadikan contoh bagi 
daerah-daerah lain yang menjadi kantong pemasok Tenaga Kerja Indonesia dengan angka perceraian yang tinggi disebabkan faktor profesi sebagai Tenaga kerja Indonesia.

\section{Penutup}

Profesi sebagai Tenaga Kerja Indonesia tidak hanya menghasilkan dampak positif dalam hal perekonomian, namun juga dampak negatif dalam rumah tangga, di antaranya adalah perceraian. Ponorogo sebagai salah satu pemasok TKI yang besar di Jawa Timur mengalami angka perceraian yang tinggi berbanding lurus dengan tingginya angka TKI yang berasal dari Ponorogo. Mayoritas perceraian tersebut juga didominasi oleh TKI. Hal ini membuat Pemerintah Daerah berinisiatif untuk mengeluarkan Peraturan Daerah tentang larangan perceraian bagi TKI yang berada di luar negeri. Perda tersebut hingga saat ini masih belum disahkan dan ditetapkan. Padahal Perda ini telah dibahas dan digodok dari sejak tahun 2015.

Dengan mempertimbangkan urgensi dan kemaslahatan yang ditaksirkan dapat meminimalisasi terjadinya perceraian di Ponorogo, sebaiknya Perda tersebut segera disahkan dan ditetapkan agar dampaknya dapat segera dirasakan oleh masyarakat. Hal ini sejalan dengan tujuan Hukum Islam yang terumuskan dalam al-kulliyyât al-khamsah, yaitu: hifzh al-dîn (melindungi agama), hifzh al-nafs (melindungi jiwa), hifzh al-'aql (melindungi akal), hifzh al-nasab (melindungi keturunan) dan hifzh al-mâl (melindungi kekayaan).

Dalam rangka meminimalisasi angka perceraian di Ponorogo, di samping mengeluarkan Perda, perlu peraturan lain tentang tidak diperbolehkannya mewakilkan kepada pengacara. Selain itu, upaya penyuluhan juga perlu dilakukan oleh Pemerintah Daerah baik pra maupun pasca pemberangkatan TKI ke luar negeri. Upaya penyuluhan pra pemberangkan dilakukan dengan cara menanamkan pada diri TKI dan keluarga bahwa perkawinan adalah komitmen yang mulia dan agung, memastikan bahwa pasangan dan keluarga mereka adalah prioritas utama dalam 
hidup, menjaga komunikasi dengan pasangan dan mengesampingkan ego pribadi. Sedangkan upaya penyuluhan pasca pemberangkatan adalah dengan mencari sumber permasalahan ketika terjadi konflik dan berupaya mencari penyelesaian sebaik-baiknya, selalu introspeksi diri, tidak membesarkan masalah, menjalin komunikasi dengan baik, dan mengingat anak sebagai objek yang akan mendapatkan dampak yang paling besar apabila terjadi perceraian.

\section{Daftar Pustaka}

Alawi (Al), Muhlis. "Pemkab Ponorogo Buat Perda Larangan TKI Cerai", dalam http://regional.kompas.com/read/2016/11/08/16443431/pemk ab.ponorogo.buat.perda.larangan.tki.cerai, diakses tanggal 28 Januari 2017.

Basyir, Ahmad Azhar. Hukum Perkawinan Islam. Yogyakarta: Bagian Penerbitan Fak. Hukum Universitas Islam Indonesia, 1977.

Dariyo, Agoes. "Memahami Psikologi Perceraian dalam Keluarga". Jurnal Psikologi, Vol 2. No 2, 2004.

Dawud, Abu. Sunan Abî Dâwud. Jilid II: 254, hadis nomor 2178, "Kitab at-Thalâq, Bab Kahariyah at-Thalâq", Beirut: Dar alFikr, 1994.

Eyato, Dili. "DPRD Godog Perda TKI Dilarang Bercerai", dalam https://daerah.sindonews.com/read/984740/151/dprd-godokperda-tki-dilarang-bercerai-1428026647 diakses tanggal 28 Januari 2017.

Hadikusuma, Hilman. Hukum Perkawinan Indonesia Menurut Perundangan, Hukum Adat, Hukum Agama Hindu-Islam, Cet.I. Bandung: Mandar Maju, 1990.

http://www.surabayapost.co.id diakses pada tanggal 20 Februari 2017.

Ihromi, T.O. Sosiologi Keluarga. Jakarta: Yayasan Obor Indonesia, 2004. 
Janeko. "Fenomena Pereceraian di Kalangan Tenaga Kerja Wanita (TKW) Hongkong dan Taiwan: Studi di Desa Kedungsalam, Kecamatan Donomulyo, Kabupaten Malang". SkripsiUniversitas Islam Negeri Maulana Malik Ibrahim Malang, 2011.

Kompilasi Hukum Islam di Indonesia, Direktorat Pembinaan Peradilan agama Islam Ditjen Pembinaan Kelembagaan Islam Departemen Agama, 2001.

Kusumaningrum, Pramita. "TKI Dominasi Angka Perceraian di Ponorogo", dalam http://beritajatim.com/hukum_kriminal/272781/tki_dominasi _angka_perceraian_di_ponorogo.html, diakses tanggal 02 Februari 2017.

M, Arif Nasution. Globalisasi dan Migrasi Antar Negara. Bandung: Alumni, 1999.

Miladiyanto, Sulthon. "Pengaruh Profesi Tenaga Kerja Indonesia (TKI) Terhadap Tingginya Perceraian di Kabupaten Malang". Jurnal Moral Kemasyarakatan, Vol. 1, No. 1, Juni, 2016.

Peraturan Daerah Provinsi Jawa Timur Nomor 4 Tahun 2016 tentang Pelayanan Penempatan dan Perlindungan Tenaga Kerja Indonesia ke Luar Negeri

Peraturan Pemerintah Nomor 10 Tahun 1983 tentang Izin Perkawinan dan Perceraian Bagi Pegawai Negeri Sipil.

Peraturan Pemerintah Nomor 45 Tahun 1990 tentang Perubahan Atas Peraturan Pemerintah Nomor 10 Tahun 1983 tentang Izin Perkawinan dan Perceraian bagi Pegawai Negeri Sipil.

Produk Hukum Tenaga Kerja Indonesia dalam http://jdih.bnp2tki.go.id/index.php?option=com_content\&vi ew=article\&id=38\&Itemid=718\&lang=en. diakses tanggal 15 Maret 2017.

Qardhawi (al-), Yusuf. Ri'ayah al-Bi'ah fi al-Syari'ah al-Islamiyyah. Kairo: Dar al-Syuruq, 2001.

Rahman, Asjmuni A. Qoidah-Qoidah Figh. Jakarta: Bulan Bintang, 1976. 
Riyani, Nanda Putri. “Analisis Pengaruh Keterlibatan Ayah Dalam Pengasuhan Terhadap Pencapaian Pendidikan Anak Di Keluarga Migran". Skripsi--Institut Pertanian Bogor, 2015.

Rofiq, Ahmad. Hukum Islam di Indonesia. Jakarta: PT. Raja Grafindo Persada, 1995.

Sastroatmojo. Hukum Perkawinan di Indonesia. Jakarta: Bulan Bintang, 1990.

Undang-Undang Republik Indonesia Nomor 1 Tahun 1974 tentang Perkawinan.

Wijaya, Putri Novita. "Faktor-Faktor yang Mempengaruhi Perceraian dalam Perkawinan". Skripsi--Universitas Katolik Soegijapranata, Semarang, 2008.

Wiyaswiyanti, Bety. "Dampak Psikologis Perceraian Pada Wanita". Skripsi--Universitas Katolik Soegijapranata, Semarang, 2008. 